\title{
FUZZY LOGIC PROGRAM FOR BUS INDOOR ENVIRONMENTAL ASSESSMENT
}

\author{
Adrian Allana and Alvin Chua \\ Mechanical Engineering Department, De La Salle University, Manila City, Philippines 1004 \\ e-mail address: adrian_allana@dlsu.edu.ph
}

Received Date: October 6, 2020; Revised Date: May 23, 2021; Acceptance Date: September 7, 2021

\begin{abstract}
This paper proposes a fuzzy logic algorithm that evaluates the indoor environmental conditions on an urban bus specifically in Metro Manila. This algorithm identifies the value of three indexes: IAQI, TCI, and $\mathrm{CO}_{2}$. The Indoor Air Quality Index (IAQI) quantifies the level of indoor air quality of the bus. $\mathrm{CO}_{2}, \mathrm{CO}, \mathrm{NO}_{2}, \mathrm{O}_{3}$, TVOC, and $\mathrm{PM}_{10}$ are the input parameters for the fuzzy logic system that will determine IAQI. Thermal Comfort Index (TCI) quantifies the indoor thermal condition in four levels. The indoor temperature and humidity are the input parameters for the fuzzy logic system that will determine TCI. The fuzzy logic program in this study is designed mainly for the bus ventilation control system. The created FLS program was able to give good results. The observations from the program were the following: as the indoor air pollutants increased, the IAQI decreased; as the level of thermal parameters increased, the TCI decreased; and as the $\mathrm{CO}_{2}$ level and temperature increased, the number of passengers also increased.
\end{abstract}

Keywords: Fuzzy logic, IAQI, TCI, Ventilation system

\section{Introduction}

Carbon dioxide is a colorless and odorless molecule that consists of one carbon and two oxygen atoms. These atoms are covalently bonded which means that an electron is shared between the atoms. Carbon dioxide makes up approximately $0.04 \%$ of the atmosphere and although this gas is not needed by humans, plants that produce oxygen, use carbon dioxide during photosynthesis and convert the carbon into sugar (glucose), a process called fixation. Humans indirectly benefit from carbon dioxide after all. The two general sources of carbon dioxide are natural and human. Natural sources come from environmental occurrences that happened without human intervention. Decomposition, ocean release, and respiration are some of the examples of these natural sources. Human sources come from human acts. Some of these acts are the burning of fossil fuels, deforestation, and industrial processes. A high concentration of carbon dioxide causes it to act as a greenhouse gas. Greenhouse gases trap heat below the atmosphere which eventually contributes to global warming.

Carbon dioxide is an essential indicator of indoor air quality. A study shows that the correlation between the carbon dioxide concentration and ventilation index is significantly negative which means that as carbon dioxide increases, ventilation declines [1]. In a study done in Michigan schools, the rate of ventilation was acquired using carbon dioxide and the number of occupants as parameters [2].

Ventilation has a great influence on indoor air quality, thermal comfort, and health. Carbon dioxide is usually associated with the ventilation rate of the occupants and the number of bio effluents. Some researchers found out that complaints about indoor air quality in an area are due to high carbon dioxide concentration and low ventilation rates [3]. 
A study on a mixed-mode ventilation system proposed the evaluation of outdoor environmental factors (humidity, temperature, and pressure differential) to determine if the outside condition is acceptable for the operation of natural ventilation in a specific type of building [4].

More than half of a person's lifetime is spent indoors. Many health hazards invisibly harm every human inside a closed area. Human health and labor productiveness are greatly affected by the indoor environment which is affected by several factors: ventilation, pollutants, humidity, temperature, and air exchange rates [5]. Six pollutants and two thermal quality indicators will be considered in this study. The pollutants are carbon dioxide $\left(\mathrm{CO}_{2}\right)$, carbon monoxide (CO), Nitrogen Dioxide $\left(\mathrm{NO}_{2}\right)$, Ozone $\left(\mathrm{O}_{3}\right)$, Total Volatile Organic Compounds (TVOC), and $\mathrm{PM}_{10}$. The two indoor conditions are the indoor temperature and humidity of the bus. The parameters chosen for this study are based on the study done by Dionova et al. (2020) [6].

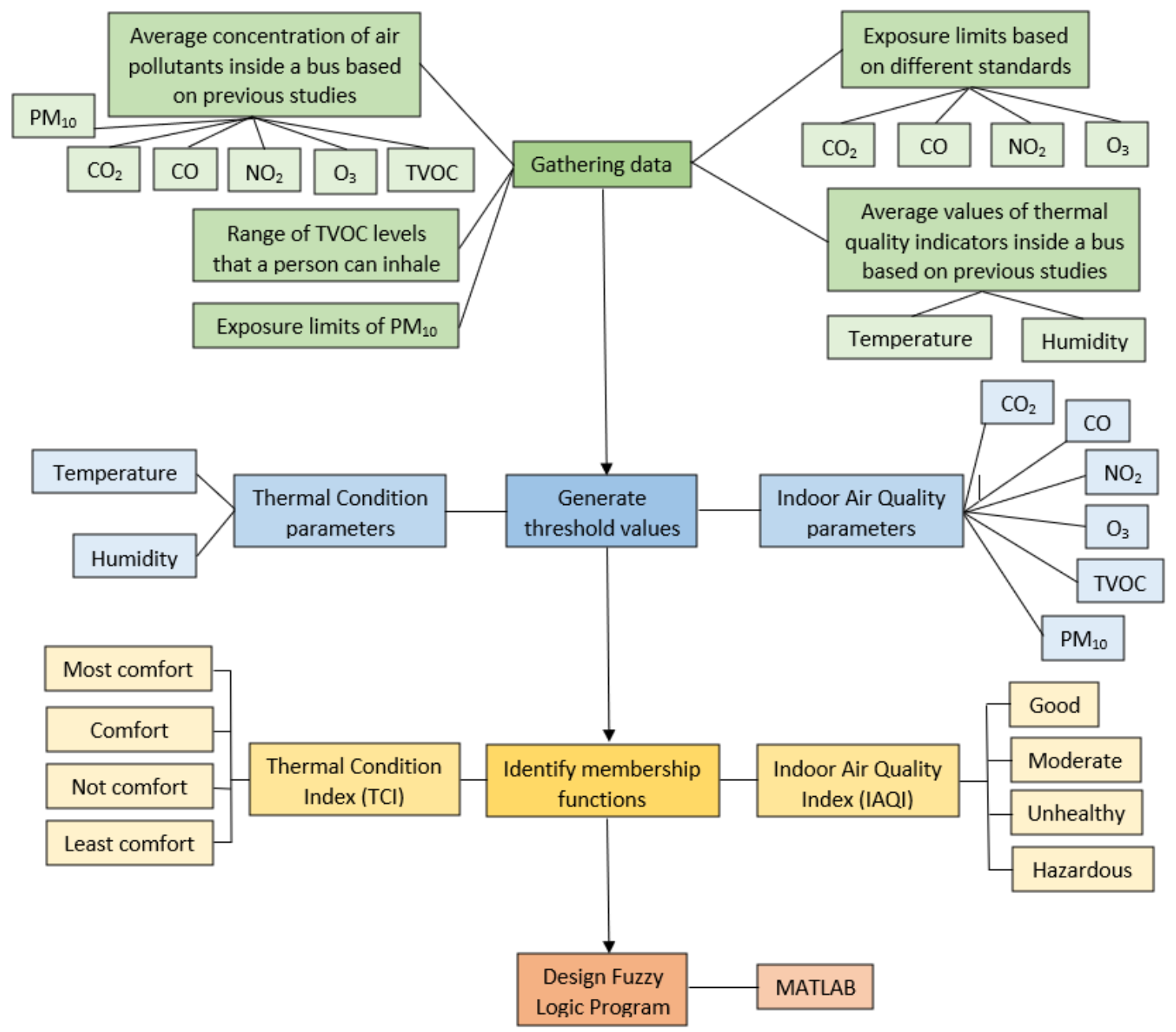

Figure 1. Idea map of the study

Above is the idea map for this study (Figure 1). First, data about average concentrations of air pollutants and thermal quality indicators inside a bus that were observed in previous studies will be collected. This can be useful in setting the minimum and maximum values of the indoor air quality and thermal quality parameters. Next is to generate the threshold values of these parameters which will then be followed by the identification of membership functions. For the parameters of thermal quality and thermal condition index 
(TCI), the classifications will be most comfort, comfort, not comfort, and least comfort. For the parameters of indoor air quality and IAQI, the classifications will be good, moderate, unhealthy, and hazardous. The IAQI and TCI will be determined using fuzzy rules which will then be discussed in the next section. The number of passengers will also be determined using the fuzzy method with $\mathrm{CO}_{2}$ and temperature as determining factors. Lastly, a fuzzy logic program will be designed using MATLAB. This FLS program will be used in a complementary study that aims at controlling the bus ventilation system using the IAQ and TQ factors used in this study.

In this study, a fuzzy logic system that can be utilized for urban bus ventilation controllers will be designed. The evaluation of IAQI and TCI in this study is different from the study of Dionova et al. (2020) in such a way that the IAQI will be determined by six pollutants instead of the four pollutants. The previous study (Dionova et al., 2020) used $\mathrm{CO}_{2}$, $\mathrm{CO}, \mathrm{NO}_{2}$, and $\mathrm{O}_{3}$ for the evaluation of IAQI. PM 2.5 , VOC, Temperature, and Humidity were used for determining TCI. In this study, VOC and $\mathrm{PM}_{2.5}$ will be eliminated from the input parameters for TCI because these criteria do not primarily define the status of thermal comfort instead, these can be more applicable in determining indoor air quality as these (VOC and $\mathrm{PM}_{2.5}$ ) share compositions in air content. Total Volatile Organic Compounds (TVOC) and $\mathrm{PM}_{10}$ were included in the input parameters for IAQI. TVOC stands for Total Volatile Organic Compound. Different compounds can be classified as VOCs and the term TVOC is used to be more specific. Examples of VOCs are benzene, toluene, ethylbenzene, $\mathrm{O}$-xylene, and many more. In this study, it is specified that the total amount of all types of VOCs will be measured. $\mathrm{PM}_{2.5}$ is changed to $\mathrm{PM}_{10}$ because the amount of $\mathrm{PM}_{10}$ is related to the amount of $\mathrm{PM}_{2.5}$ and coarse particles which means that it acts as a representative for other types of particulate matter [3]. Thermal Comfort Index (TCI) is to be determined by only two parameters: temperature and humidity.

\section{Theory}

\section{Pollutants Exposure Limits and Ranges of Concentration Inside Buses}

The range of the membership functions of the pollutants is based on previous studies. Although the membership functions that are used in this study are based on the study of Dionova et al. (2020) [6], the exposure limits of the pollutants are reviewed to know if the threshold values used by the said study apply to urban buses. The exposure limits will be the basis for acceptable indoor air quality conditions. Table 1 shows the exposure limits of $\mathrm{CO}_{2}$, $\mathrm{CO}, \mathrm{NO}_{2}$, and $\mathrm{O}_{3}$. The standards are taken from Health Canada Exposure Guidelines for Residential Indoor Air Quality (Canadian), ASHRAE, OSHA, WHO, and U.S. EPA National Ambient Air Quality Standards (NAAQS/EPA)

Table 1. Exposure Limits Based on Different Standards

\begin{tabular}{|c|c|c|c|}
\hline $\mathrm{CO}_{2}(\mathrm{ppm})$ & CO (ppm) [7] & $\mathrm{NO}_{2}(\mathrm{ppm})[7]$ & $\mathbf{O}_{3}$ (ppm) [7] \\
\hline \multirow{6}{*}{$\begin{array}{c}1000 \text { (ASHRAE } \\
\text { \& OSHA) } \\
5000 \text { (OSHA) [7] }\end{array}$} & 25.0 (1 h) (Canadian) & 0.09 (1 h) (Canadian) & 0.02 (8 h) (Canadian) \\
\hline & $28.0(1 \mathrm{~h})(\mathrm{WHO})$ & 1 (15 min) (NIOSH REL) & $0.2(<=2 \mathrm{~h})$ ACGIH \\
\hline & 35.0 (1 h) (NAAQS/EPA) & 5 (C) (OSHA) & \\
\hline & 35.0 (NIOSH REL) & & \\
\hline & 50.0 (OSHA) & & \\
\hline & $25.0($ ACGIH $)$ & & \\
\hline
\end{tabular}


Table 2 shows the average concentrations inside buses in different countries. The range of $\mathrm{CO}_{2}$ concentration is based on the thesis study of Allana, Docta, Javier, Ong, \& Razo (2016) [8]. Although this study is not published, the researcher himself (Allana) was part of the group who conducted the said study so the data that will be used for this study is reliable. The other air pollutants $\left(\mathrm{CO}\right.$ and $\left.\mathrm{NO}_{2}\right)$ were taken from other studies [9][10].

Table 2. Average Concentration of Air Pollutants Inside a Bus Based on Previous Studies

\begin{tabular}{cccc}
\hline $\mathbf{C O}_{2}$ (ppm) & $\mathbf{C O}$ (ppm) [9] & $\mathbf{N O}_{2}$ (ppm) [10] & $\mathbf{O}_{3}$ (ppm) \\
\hline 1000-8000 & 2.00 (HK) & $0.0150-0.0310$ (Texas) & No study was \\
$(\mathrm{Phl})[8]$ & found. & \\
& 11.6 (Taipei) & 0.0440 (Sydney) & \\
& 8.20-10.0 (Denver) & 0.0690 (Hong Kong) & \\
& 4.00-8.00 (Washington) & 0.1080 (Paris) & \\
& & 0.0310 (Perth) & \\
& & 0.0709 (Birmingham) & \\
\hline
\end{tabular}

Table 3 shows the average values of thermal quality indicators and indoor air pollutants. These numbers were taken from previous studies that involved urban buses. The first two columns show the average values of TCI input parameters. The third column shows the average values of TVOC taken from three countries [11][12][13]. There are no values shown in the fourth column because there were no studies found that provide $\mathrm{PM}_{10}$ measurements inside a bus.

Table 3. Average Values of Thermal Quality Indicators and Indoor Air Pollutants Inside a Bus Based on Previous Studies

\begin{tabular}{cccc}
\hline $\begin{array}{c}\text { Temperature } \\
\left({ }^{\circ} \mathbf{C}\right)\end{array}$ & $\begin{array}{c}\text { Humidity } \\
(\%)\end{array}$ & TVOC & PM10 \\
\hline $20-30[8]$ & $40-60[8]$ & $195.00 \mu \mathrm{g} / \mathrm{m}^{3}$ (Taegu,Korea) [11] & \\
& & $2164.2 \mu \mathrm{g} / \mathrm{m}^{3}$ (Taipei, Taiwan) [12] & \\
& & $53.000 \mu \mathrm{g} / \mathrm{m}^{3}$ (Prague, CR) [13] & \\
\hline
\end{tabular}

Table 4 shows the range of TVOC with the level of acceptability based on human health hazards. The data used in Table 4 is taken from [14]. This data is used as a reference for the membership function of TVOC.

Table 4. Acceptable TVOC Levels that a Person can Inhale [14]

\begin{tabular}{cc}
\hline TVOC Level $\mathbf{~ m g} / \mathbf{m}^{3}$ & Level of Concern \\
\hline$<0.3 \mathrm{mg} / \mathrm{m}^{3}$ & Low \\
\hline 0.3 to $0.5 \mathrm{mg} / \mathrm{m}^{3}$ & Acceptable \\
\hline 0.5 to $1 \mathrm{mg} / \mathrm{m}^{3}$ & Marginal \\
\hline 1 to $3 \mathrm{mg} / \mathrm{m}^{3}$ & High \\
\hline
\end{tabular}


Table 5 shows the exposure limits of $\mathrm{PM}_{10}$ based on different standards [15][16]. These values are used as the basis for the membership function of $\mathrm{PM}_{10}$ which is necessary for generating a fuzzy logic system.

Table 5. Exposure Limits of PM10 Based on Different Standards

\begin{tabular}{cc}
\hline Standards & PM10 Exposure Limit \\
\hline European Union [15] & $50.00 \mu \mathrm{g} / \mathrm{m}^{3}$ (24 hrs. averaging period) \\
& $40.00 \mu \mathrm{g} / \mathrm{m}^{3}$ (1-year averaging period) \\
National Ambient Air Quality Standard [16] & $150.0 \mu \mathrm{g} / \mathrm{m}^{3}$ (24-hour average) \\
California Ambient Air Quality Standard [16] & $50.00 \mu \mathrm{g} / \mathrm{m}^{3}$ (24-hour average) \\
\hline
\end{tabular}

\section{Threshold Values}

The threshold values for the parameters were taken from the study of Dionova et al. (2020) [6]. The values were reviewed and adjusted for urban bus applications. Table 6 shows the IAQI parameters $\left(\mathrm{CO}_{2}, \mathrm{CO}, \mathrm{NO}_{2}, \mathrm{O}_{3}\right.$, TVOC, and $\left.\mathrm{PM}_{10}\right)$ and how they will be defined in four levels (Good, Moderate, Unhealthy, and Hazardous). The range of $\mathrm{CO}_{2}$ concentration is increased to $8000 \mathrm{ppm}$ because the highest recorded level of $\mathrm{CO}_{2}$ almost reached $8000 \mathrm{ppm}$ (Figure 4). The other parameters were reviewed. The basis in determining the threshold points for $\mathrm{CO}_{2}, \mathrm{CO}, \mathrm{NO}_{2}$, and $\mathrm{O}_{3}$ are from the data presented in Table 1 and Table 2. The value of a parameter will fall under "good" or "moderate" membership if it is within the standards stated in Table 1. Meanwhile, the basis in determining the threshold points for TVOC and $\mathrm{PM}_{10}$ are the data presented in Tables 3 to 5 . All values on the first row correspond to "Good" membership. All values on the second row correspond to "Moderate" membership. All values on the third row correspond to "Unhealthy" membership. All values on the last row correspond to "Hazardous" membership.

Table 6. Threshold Points for IAQI Parameters

\begin{tabular}{|c|c|c|c|c|c|c|c|}
\hline $\begin{array}{c}\mathrm{CO}_{2} \\
(\mathrm{ppm})\end{array}$ & $\begin{array}{c}\mathrm{CO} \\
(\mathrm{ppm})\end{array}$ & $\begin{array}{c}\mathrm{NO}_{2} \\
(\mathrm{ppm})\end{array}$ & $\mathrm{O}_{3}(\mathrm{ppm})$ & $\begin{array}{c}\text { TVOC } \\
\left(\mathrm{mg} / \mathrm{m}^{3}\right)\end{array}$ & $\begin{array}{c}\mathrm{PM}_{10} \\
\left(\mathrm{mg} / \mathbf{m}^{3}\right)\end{array}$ & IAQI & Membership \\
\hline 0-606 & $0-2$ & $0-0.025$ & $0-0.028$ & $0.0-0.3$ & $0.00-0.03$ & $1-1.5$ & Good \\
\hline 520-1020 & $1.8-8.5$ & $0.02-0.2$ & $\begin{array}{c}0.025- \\
0.055\end{array}$ & $0.3-0.5$ & $0.02-0.05$ & $0.5-1$ & Moderate \\
\hline 800-1520 & $7-10$ & $0.09-0.4$ & $0.05-0.08$ & $0.40-1.1$ & $0.04-0.16$ & $0-0.5$ & Unhealthy \\
\hline $\begin{array}{c}1480- \\
8000\end{array}$ & $9-50$ & $0.3-5$ & $0.076-0.1$ & $1.0-3.0$ & $0.15-0.20$ & $-1.5-0$ & Hazardous \\
\hline
\end{tabular}

The temperature and humidity are adjusted based on the data recorded by the researcher's previous study on urban buses [8]. Table 7 shows the TCI parameters (Temperature and Humidity) and how they will be defined in four levels (Most Comfort, Comfort, Not Comfort, and Least Comfort). All values on the first row correspond to "Most comfort" membership. All values on the second row correspond to "Comfort" membership. All values on the third row correspond to "Not comfort" membership. All values on the last row correspond to "Least comfort" membership. 
Table 7. Threshold Points for TCI Parameters

\begin{tabular}{cccc}
\hline Temperature $\left({ }^{\circ} \mathbf{C}\right)$ & Humidity (\%) & TCI & Membership \\
\hline $20.0-25.0$ & $40.0-45.0$ & $2.25-3.00$ & Most Comfort \\
\hline $24.0-27.0$ & $45.0-51.0$ & $1.50-2.25$ & Comfort \\
\hline $26.0-28.0$ & $50.0-55.0$ & $0.750-1.50$ & Not Comfort \\
\hline $27.5-30.0$ & $54.0-60.0$ & $0.00-0.75$ & Least Comfort \\
\hline
\end{tabular}

The threshold points presented in Table 8 (for the number of passengers) are based on the researcher's data which can be seen in Figures 4, 5, and 6. The researcher approximately decided what the values will be for a given membership function. The full capacity of an urban bus is 50 passengers. The indoor $\mathrm{CO}_{2}$ concentration and temperature will serve as input parameters for a fuzzy logic system that will determine the number of passengers inside the bus. This method of determining the number of passengers is supported by the chart shown in Figures 4 and 5. In Figure 4, the average $\mathrm{CO}_{2}$ concentration increased as the number of passengers increased. Same with Figure 5 where temperature also increased as the number of passengers increased. The fuzzy rules were designed and calibrated based on the actual data gathered by the researcher. The membership labels of $\mathrm{CO}_{2}$ and passengers are combined in the third column of Table 8. The membership labels of $\mathrm{CO}_{2}$ concentration are divided into eight $(1 \mathrm{k}, 2 \mathrm{k}, 3 \mathrm{k} . .8 \mathrm{k})$. The same goes for membership labels of the number of passengers $(0-20,10-30,20-40 \ldots 70-80)$.

Table 8. Threshold Points for The Number of Passengers and its Input Parameters

\begin{tabular}{cccccc}
\hline $\begin{array}{c}\mathbf{C O} 2 \\
\mathbf{p p m})\end{array}$ & Passengers & $\begin{array}{c}\text { Membership } \\
\left(\mathbf{C O}_{2}\right)\end{array}$ & $\begin{array}{c}\text { Membership } \\
\text { (Passengers) }\end{array}$ & $\begin{array}{c}\text { Temperature } \\
\left({ }^{\circ} \mathbf{C}\right)\end{array}$ & Membership \\
\hline $0-2000$ & $0.0-20$ & $1 \mathrm{k}$ & 10 & $20-25$ & Low \\
\hline $1000-3000$ & $10-30$ & $2 \mathrm{k}$ & 20 & $24-29$ & Medium \\
\hline $2000-4000$ & $20-40$ & $3 \mathrm{k}$ & 30 & $28-30$ & High \\
\hline $3000-5000$ & $30-50$ & $4 \mathrm{k}$ & 40 & & \\
\hline $4000-6000$ & $40-60$ & $5 \mathrm{k}$ & 50 & & \\
\hline $5000-7000$ & $50-70$ & $6 \mathrm{k}$ & 60 & & \\
\hline $6000-8000$ & $60-80$ & $7 \mathrm{k}$ & 70 & & \\
\hline $7000-8000$ & $70-80$ & $8 \mathrm{k}$ & 80 & & \\
\hline
\end{tabular}

\section{Fuzzy Rules for IAQI and TCI}

The fuzzy rules for determining IAQI and TCI in Tables 9 and 10 are based on fuzzy rules created by Dionova et al. (2020) [6]. The fuzzy logic system is generated using MATLAB. The second column of Table 9 represents the membership of $\mathrm{CO}, \mathrm{NO}_{2}$, and TVOC. The 
second row represents the membership of $\mathrm{CO}_{2}, \mathrm{O}_{3}$, and $\mathrm{PM}_{10}$. The remaining table (with font color black) determines the IAQI membership. The rules are used in this manner, for example, if the measured values of $\mathrm{CO} / \mathrm{NO}_{2} / \mathrm{TVOC}$ (with font color green) fall under "Good" membership and the values of $\mathrm{CO}_{2} / \mathrm{O}_{3} / \mathrm{PM}_{10}$ (with font color red) fall under "Moderate" membership then the IAQI will be equivalent to "Moderate".

Table 9. Fuzzy Rules for IAQI

\begin{tabular}{llllll}
\hline & & \multicolumn{4}{c}{$\mathrm{CO}_{2} / \mathrm{O}_{3} / \mathbf{P M}_{10}$} \\
\hline & Good & Moderate & Unhealthy & Hazardous \\
\hline & Good & Good & Moderate & Moderate & Unhealthy \\
\cline { 2 - 6 } CO/NO2/TVOC & Moderate & Moderate & Moderate & Unhealthy & Unhealthy \\
\cline { 2 - 6 } & Unhealthy & Moderate & Unhealthy & Unhealthy & Unhealthy \\
\cline { 2 - 6 } & Hazardous & Unhealthy & Unhealthy & Unhealthy & Hazardous \\
\hline
\end{tabular}

In table 10, the second column (with font color green) represents the membership of temperature. The second row (with font color red) represents the membership of humidity. The remaining table (with font color black) determines the membership of TCI. The fuzzy rules for TCI follow the procedure in the fuzzy rules for IAQI (Table 9).

Table 10. Fuzzy Rules for TCI

\begin{tabular}{|c|c|c|c|c|c|}
\hline & & \multicolumn{4}{|c|}{ Humidity } \\
\hline & & $\begin{array}{l}\text { Most } \\
\text { Comfort }\end{array}$ & Comfort & $\begin{array}{c}\text { Not } \\
\text { Comfort }\end{array}$ & $\begin{array}{l}\text { Least } \\
\text { Comfort }\end{array}$ \\
\hline \multirow{4}{*}{ Temperature } & $\begin{array}{c}\text { Most } \\
\text { Comfort }\end{array}$ & $\begin{array}{l}\text { Most } \\
\text { Comfort }\end{array}$ & Comfort & Comfort & $\begin{array}{c}\text { Not } \\
\text { Comfort }\end{array}$ \\
\hline & Comfort & Comfort & Comfort & $\begin{array}{c}\text { Not } \\
\text { Comfort }\end{array}$ & $\begin{array}{c}\text { Not } \\
\text { Comfort }\end{array}$ \\
\hline & $\begin{array}{c}\text { Not } \\
\text { Comfort }\end{array}$ & Comfort & $\begin{array}{c}\text { Not } \\
\text { Comfort }\end{array}$ & $\begin{array}{c}\text { Not } \\
\text { Comfort }\end{array}$ & $\begin{array}{c}\text { Not } \\
\text { Comfort }\end{array}$ \\
\hline & $\begin{array}{l}\text { Least } \\
\text { Comfort }\end{array}$ & $\begin{array}{c}\text { Not } \\
\text { Comfort }\end{array}$ & $\begin{array}{c}\text { Not } \\
\text { Comfort }\end{array}$ & $\begin{array}{c}\text { Not } \\
\text { Comfort }\end{array}$ & $\begin{array}{c}\text { Least } \\
\text { Comfort }\end{array}$ \\
\hline
\end{tabular}

The fuzzy rules for determining the number of passengers are presented in Table 11. The number of passengers depended more on the $\mathrm{CO}_{2}$ concentration than the temperature because the temperature is affected by the weather and air-conditioning system whereas $\mathrm{CO}_{2}$ is greatly affected by the number of passengers. There is a correlation between $\mathrm{CO}_{2}$ level and the number of passengers since the passengers of the bus greatly contribute to the $\mathrm{CO}_{2}$ production inside the bus. 
Table 11. Fuzzy Rules for The Number of Passengers

\begin{tabular}{|c|c|c|c|c|}
\hline \multicolumn{5}{|c|}{ Fuzzy Rules: Number of Passengers } \\
\hline & & \multicolumn{3}{|c|}{ Temperature $\left({ }^{\circ} \mathrm{C}\right)$} \\
\hline & & Low & Medium & High \\
\hline \multirow{8}{*}{$\mathrm{CO}_{2}(\mathrm{ppm})$} & $1 \mathrm{k}$ & 10 & 10 & 20 \\
\hline & $2 \mathrm{k}$ & 10 & 20 & 30 \\
\hline & $3 \mathrm{k}$ & 20 & 30 & 40 \\
\hline & $4 \mathrm{k}$ & 30 & 40 & 50 \\
\hline & $5 \mathrm{k}$ & 40 & 50 & 60 \\
\hline & $6 \mathrm{k}$ & 50 & 60 & 70 \\
\hline & $7 \mathrm{k}$ & 60 & 70 & 80 \\
\hline & $8 \mathrm{k}$ & 60 & 70 & 80 \\
\hline
\end{tabular}

\section{Methodology}

The design of the Fuzzy Logic System (FLS) found in Figure 2 is based on the study of Dionova et al. (2020) [6]. The parameters are grouped into two, namely, IAQI and TCI. IAQI stands for Indoor Air Quality Index while TCI stands for Thermal Comfort Index. The input parameters under IAQI are $\mathrm{CO}_{2}, \mathrm{CO}, \mathrm{NO}_{2}, \mathrm{O} 3, \mathrm{TVOC}$, and $\mathrm{PM}_{10}$. The input parameters under IAQI are grouped into three fuzzy logic systems (FLS). IAQ 1 is the first FLS that will evaluate $\mathrm{CO}_{2}$ and CO. IAQ2 is the second FLS that will evaluate $\mathrm{NO}_{2}$ and $\mathrm{O}_{3}$. IAQ3 is the third FLS that will evaluate TVOC and $\mathrm{PM}_{10}$. After getting the IAQI values for each group, the values will be added up. The total sum of IAQ $1, I_{2} Q_{2}$, and IAQ 3 is the IAQI. The temperature and humidity are used to determine the TCI.

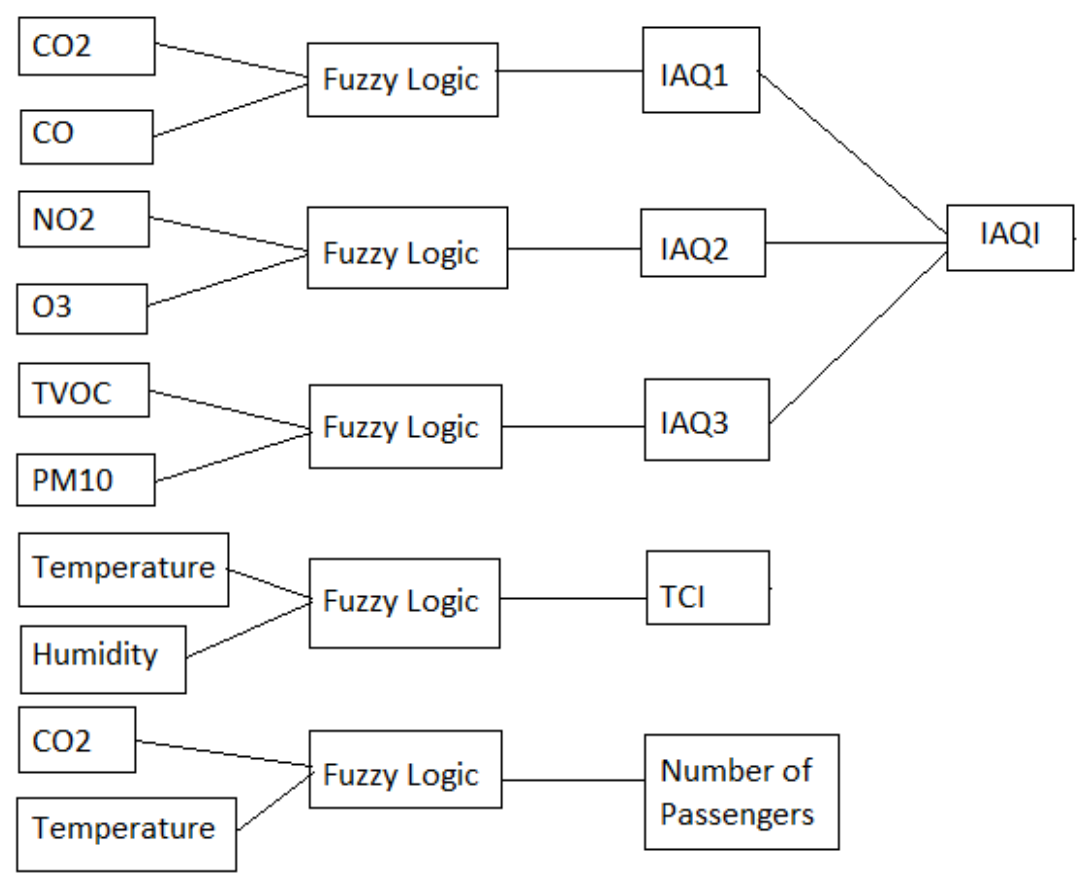

Figure 2. Fuzzy Logic System 


\section{Results}

The researcher together with his (undergraduate) colleagues researched the ventilation assessment inside a public urban air-conditioned bus in Metro Manila. The route of the buses in the study is in EDSA. The researchers used a measuring device called $\mathrm{CO}_{2}$ Meter (Benetech GM8802 Carbon Dioxide Meter) that has an actual range of 0-8200 ppm with the basic error of $\pm 50 \mathrm{ppm}$ and response time $<30$ seconds (Figure 3). It can also measure humidity and temperature. The measurements were monitored in the front, middle, back, and outside of the bus in three different parts of the day (morning, noon, and evening). The datagathering is conducted for six non-consecutive days (February 17, 2016 to March 20, 2016) [8]. The gathered data are the sources of the charts illustrated in Figures 4, 5, and 6.

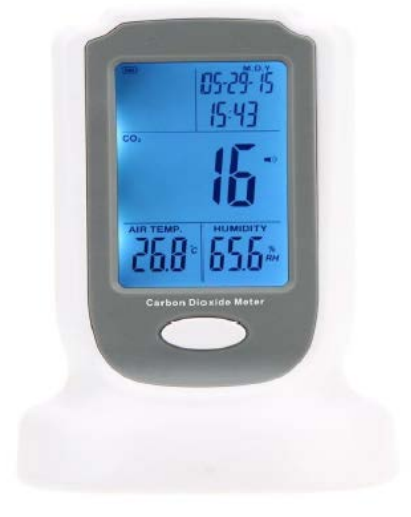

Figure 3. Benetech GM8802 carbon dioxide meter

The membership function for carbon dioxide concentration and the number of passengers is based on the researcher's thesis study. In their study, the $\mathrm{CO}_{2}$, temperature, and humidity readings were gathered in the front, middle, and back parts of the bus. The $\mathrm{CO}_{2}$ level outside the bus was also recorded. Figure 4 illustrates the level of $\mathrm{CO}_{2}$ concentration for a particular range of passengers. It can be concluded that as the number of passengers increases, the $\mathrm{CO}_{2}$ concentration inside the bus also increases [8].

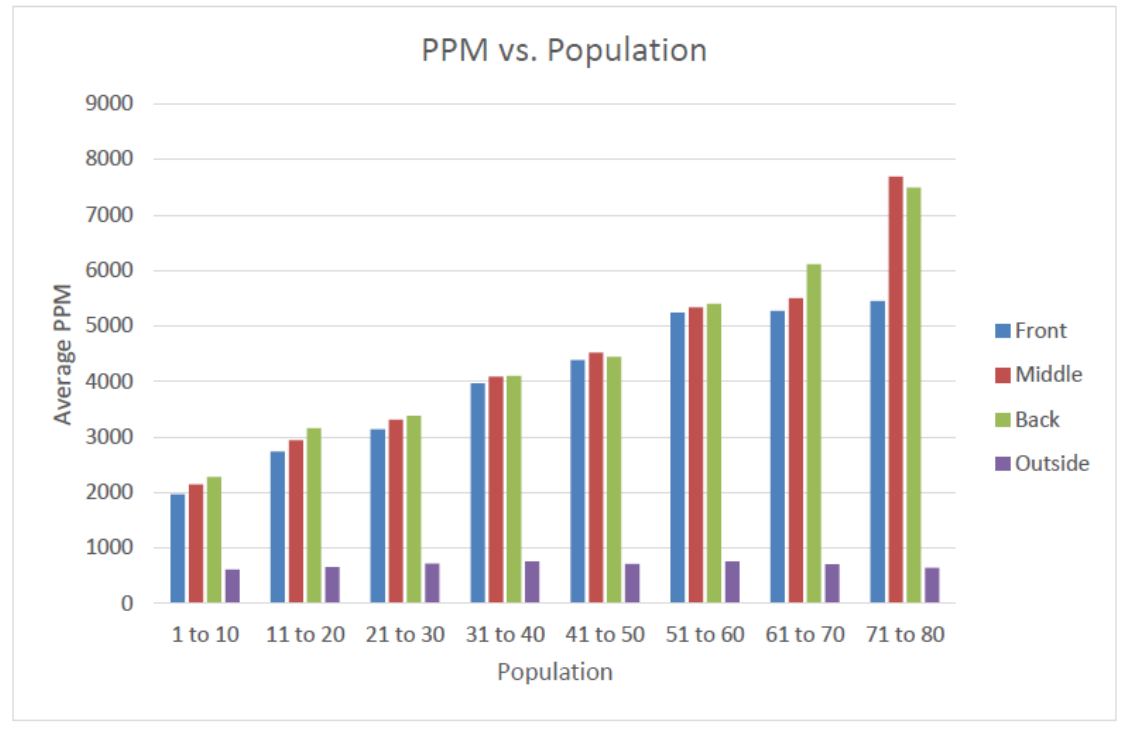

Figure 4. Average $\mathrm{CO}_{2}$ concentration as a function of the number of passengers inside an air-conditioned urban bus [8] 
In Figure 5, a discrepancy can be seen in the domain of 0-10 passengers because the temperature is quite high compared to the temperature for 11-20 passengers. The temperature for a lesser population should be lower than the temperature with a higher population because humans generate heat. The discrepancy can also be seen in ranges 6180 (population) wherein the temperature is lesser than the lower ranges of the population. The errors in Figure 5 might be caused by the small quantity of data recorded in these domains of data. During the gathering of data, buses having ranges of $0-10$ and $71-80$ passengers rarely happened. Having a small amount of data to compare can affect the accuracy of the parameter being measured. In this study, an average temperature setting is assumed at 25 to $26{ }^{\circ} \mathrm{C}$ for $0-10$ passengers and about $28-30{ }^{\circ} \mathrm{C}$ for $61-80$ passengers.

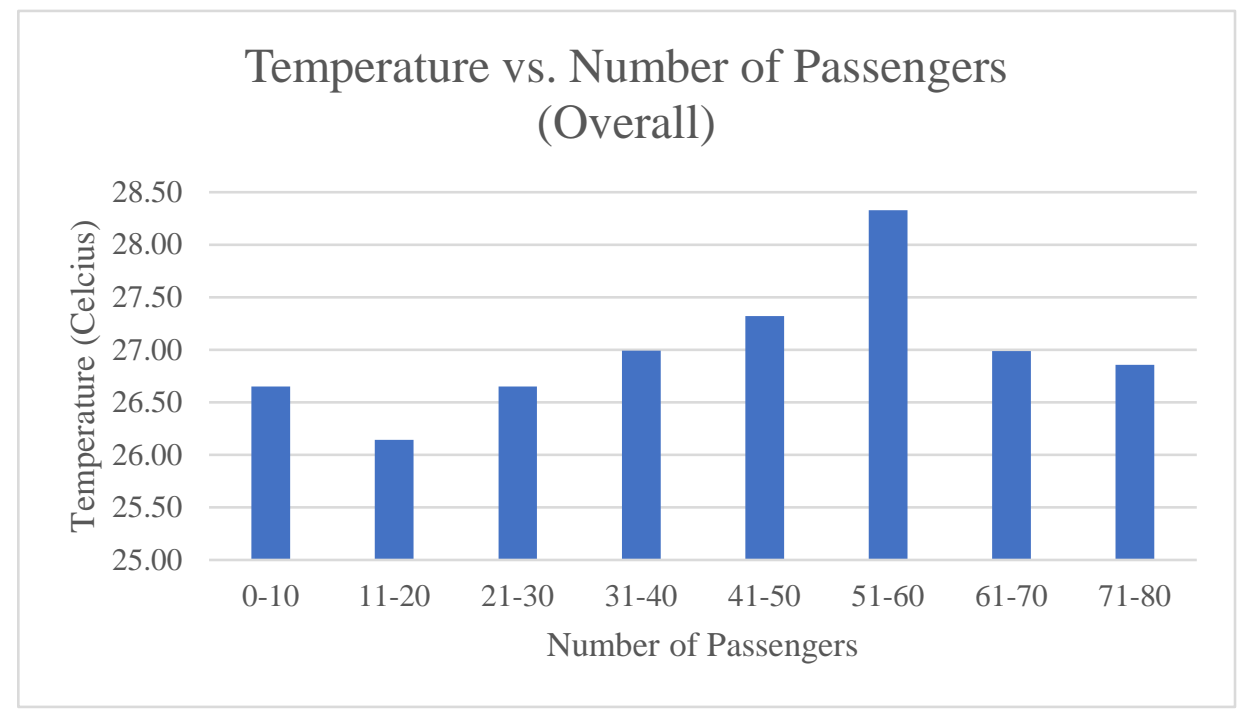

Figure 5. Average temperature as a function of the number of passengers inside an airconditioned urban bus [8]

In Figure 6, it can be seen the humidity inside the bus is maintained between $40 \%$ and $60 \%$. The lowest humidity is recorded when the bus had $0-10$ passengers. The humidity exceeded 50\% when the number of passengers inside the bus ranged from 61-80.

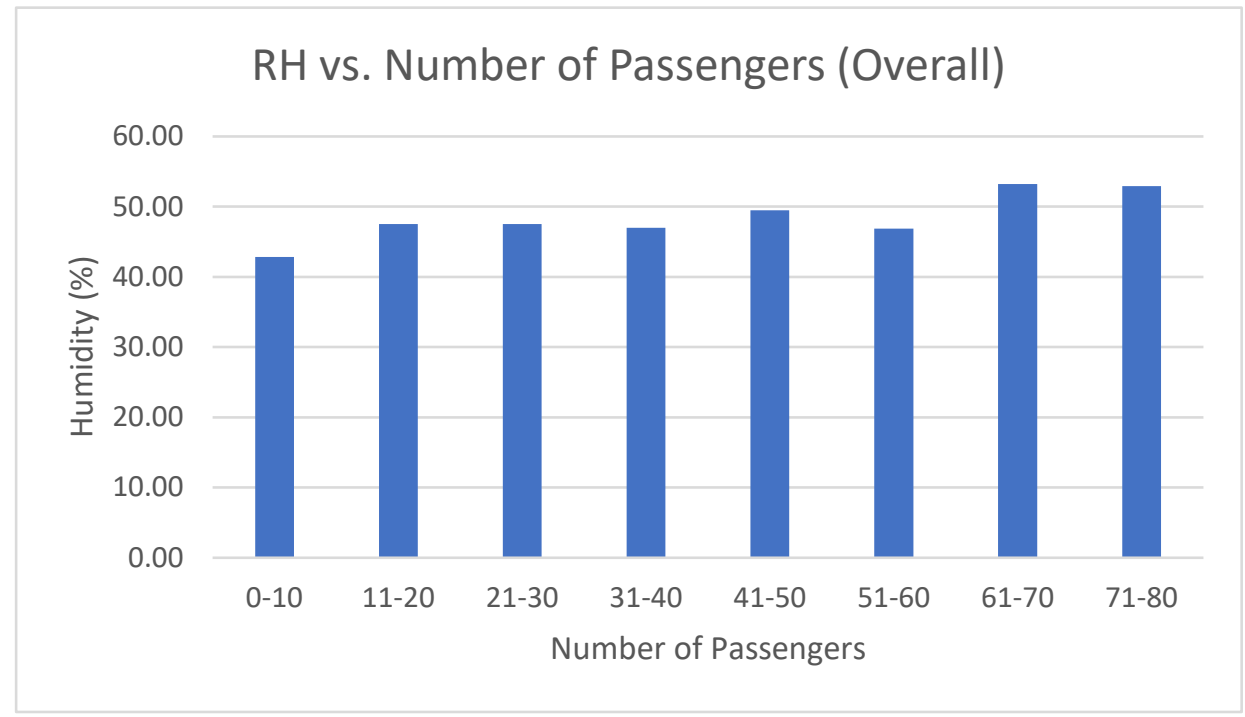

Figure 6. Average humidity as a function of the number of passengers inside an airconditioned urban bus [8] 
The main result of this study is a fuzzy logic program that was generated using MATLAB. Figure 7 shows the MATLAB rule viewer made for determining IAQ ${ }_{1}$ and IAQ 2 . $\mathrm{CO}_{2}$ and $\mathrm{CO}$ are the input parameters for IAQ ${ }_{1}$. For IAQ 2 , the input parameters are $\mathrm{NO}_{2}$ and $\mathrm{O}_{3}$. Figure 8 shows the MATLAB rule viewer for IAQ 3 and TCI. The input parameters for $\mathrm{IAQ}_{3}$ are TVOC and $\mathrm{PM}_{10}$. For TCI, the input parameters are temperature and humidity. Figure 9 illustrates the MATLAB rule viewer for determining the number of passengers. The input parameters used to determine the number of passengers through fuzzy logic are the indoor $\mathrm{CO}_{2}$ concentration and temperature.
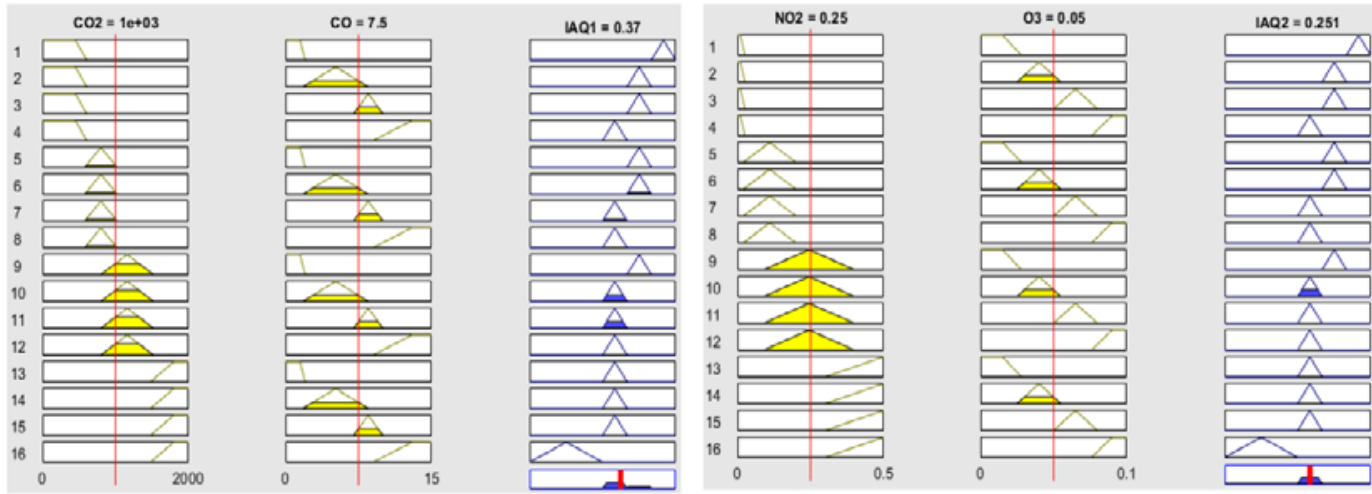

Figure 7. MATLAB rule viewer for $\mathrm{IAQ}_{1}$ (left) and $\mathrm{IAQ}_{2}$ (right)
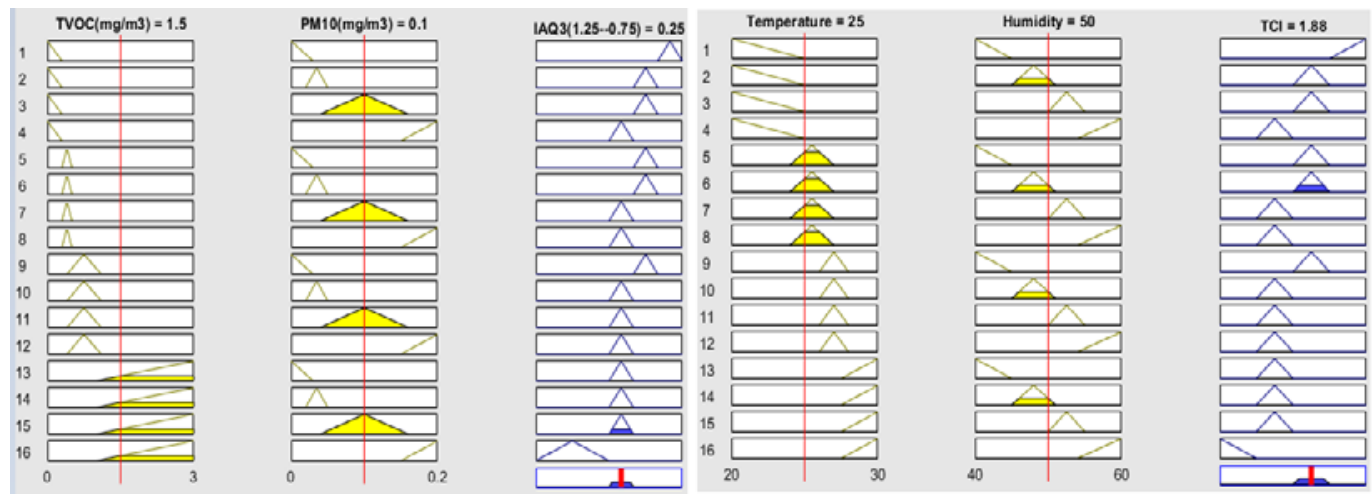

Figure 8. MATLAB rule viewer for $\mathrm{IAQ}_{3}$ (left) and TCI (right)

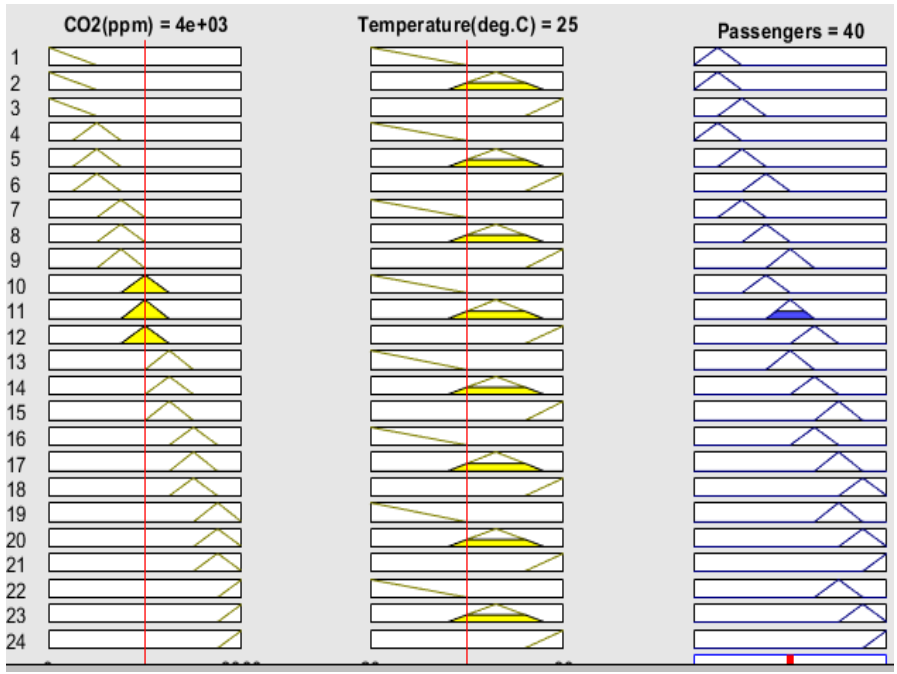

Figure 9. MATLAB rule viewer for the number of passengers 
The rule viewer of MATLAB is used to enter different input values to see the results. In Table 12, different input values of $\mathrm{IAQ}_{1}, \mathrm{IAQ}_{2}$, and $\mathrm{IAQ}_{3}$ are entered into the rule viewer to see the IAQ results and to examine how the FLS will function. Input values that exemplify each membership status are simulated in four cases: Case 1 - Good, Case 2 Moderate, Case 3 - Unhealthy, Case 4 - Hazardous. It was observed that as the indoor air pollutants increased, the IAQI decreased.

Table 12. Results of Input Values of IAQ 1 , IAQ 2 , and IAQ 3

\begin{tabular}{cccccccccc}
\hline Case & $\mathbf{C O}_{2}$ & $\mathbf{C O}$ & IAQ$_{1}$ & $\mathbf{N O}_{2}$ & $\mathbf{O}_{3}$ & IAQ $_{2}$ & TVOC $^{2}$ PM10 $_{10}$ & IAQ $_{3}$ \\
\hline 1 & 500 & 1 & 1.25 & 0.01 & 0.01 & 1.25 & 0.2 & 0.01 & 1.25 \\
\hline 2 & 1000 & 6 & 0.339 & 0.08 & 0.03 & 0.75 & 0.35 & 0.035 & 0.75 \\
\hline 3 & 1200 & 8 & 0.251 & 0.2 & 0.06 & 0.251 & 0.9 & 0.1 & 0.251 \\
\hline 4 & 6000 & 30 & -0.75 & 3 & 0.1 & -0.75 & 3 & 0.2 & -0.75 \\
\hline
\end{tabular}

Table 13 shows the different input values of TCI that are entered into the rule viewer to see the TCI output and examine how the FLS will function. Input values that exemplify each membership status are simulated in four cases: Case 1-Most Comfort, Case 2-Comfort, Case 3-Not Comfort, Case 4-Least Comfort. It was observed that as the temperature and humidity increased, the TCI decreased.

Table 13. Results of Input Values of TCI

\begin{tabular}{cccc}
\hline Case & Temperature & Humidity & TCI \\
\hline 1 & 20.0 & 40.0 & 2.76 \\
\hline 2 & 25.5 & 47.0 & 1.87 \\
\hline 3 & 26.0 & 53.0 & 1.12 \\
\hline 4 & 30.0 & 60.0 & 0.24 \\
\hline
\end{tabular}

Table 14 shows the different input values of the number of passengers that are entered into the rule viewer to see the number of passengers and examine how the FLS will function. Input values that exemplify each membership status were simulated in four cases. Since the $\mathrm{CO}_{2}$ input parameter has 8 membership status, only four were chosen. Some $\mathrm{CO}_{2}$ input values that can represent two membership statuses are used. See Table 8 to understand better the input values and membership status used in the simulation. It was observed that as the $\mathrm{CO}_{2}$ level and temperature increased, the number of passengers also increased.

Table 14. Results of Input Values of Number of Passengers

\begin{tabular}{cccc}
\hline Case & $\mathbf{C O}_{2}$ & Temperature & $\begin{array}{c}\text { No. of } \\
\text { Passengers }\end{array}$ \\
\hline 1 & 600 & 20 & 10 \\
\hline 2 & 3000 & 25 & 30 \\
\hline 3 & 4500 & 27 & 45 \\
\hline 4 & 8000 & 30 & 77 \\
\hline
\end{tabular}




\section{Conclusions}

Many studies considered using fuzzy logic to analyze environmental conditions in different locations. The indoor and outdoor environments were both examined. In this research, the indoor environmental quality of an urban bus is analyzed by using fuzzy logic. The FLS created through this study can be utilized in a bus ventilation control system. The indoor air quality is determined using different parameters. Determining these parameters will give a perception of how good indoor air quality is. This can be utilized in equipment used in maintaining IAQ. In this study, the indoor air quality and thermal comfort in an urban bus were evaluated which can be useful in controlling the ventilation system. The parameters that were used to determine the indoor air quality are $\mathrm{CO}_{2}, \mathrm{CO}, \mathrm{NO}_{2}, \mathrm{O}_{3}, \mathrm{TVOC}$, and $\mathrm{PM}_{10}$. Temperature and humidity were used to evaluate the thermal comfort inside the bus. This paper used a fuzzy logic system that can administer the decision-making process of a $\mathrm{CO}_{2}$ variable demand ventilation system. $\mathrm{CO}_{2}$ concentration, Indoor Air Quality Index (IAQI), and Thermal Comfort Index (TCI) are used as variables that will determine the overall indoor environmental quality of an urban bus that can be utilized in bus ventilation systems. The results from the case studies showed that lower values of air pollutants gave high IAQ levels and as the values increased, the IAQ level decreased. For example, $500 \mathrm{ppm}$ of $\mathrm{CO}_{2}$ and 1 ppm of CO resulted in an IAQ of 1.25. A $500 \mathrm{ppm} \mathrm{CO}_{2}$ level and $1 \mathrm{ppm} \mathrm{CO}$ level are low and not hazardous to health based on environmental standards and previous studies. $\mathrm{A} \mathrm{CO}_{2}$ level of $6000 \mathrm{ppm}$ and a CO level of $30 \mathrm{ppm}$ resulted in a negative IAQ. The same was also observed for the case studies done for the TCI. The TCI level was high when the temperature and humidity readings were low. As the readings increased, the TCI level decreased. For example, at $20{ }^{\circ} \mathrm{C}$ and $40 \%$ humidity, the TCI is 2.76 which is high. On the other hand, at $30{ }^{\circ} \mathrm{C}$ and $60 \%$ humidity, the TCI is 0.24 which is low. For the case studies for determining the number of passengers, it was observed that as the $\mathrm{CO}_{2}$ level and temperature increased, the number of passengers also increased. At $600 \mathrm{ppm}\left(\mathrm{CO}_{2}\right)$ and $20{ }^{\circ} \mathrm{C}$, the number of passengers is 10 but when the parameters were increased to $8000 \mathrm{ppm}\left(\mathrm{CO}_{2}\right)$ and $30{ }^{\circ} \mathrm{C}$, the number of passengers is 77 .

\section{References}

[1] D.S. Volkov, K.S. Morozov, and V.K. Makukha, "Development of carbon dioxide sensor for HVAC-system," International Conference of Young Specialists on Micro/Nanotechnologies and Electron Devices, pp. 582-585, 2015. doi: 10.1109/EDM.2015.7184610

[2] C. Godwin, and S. Batterman, "Indoor air quality in Michigan schools," Indoor Air, Vol. 17, No. 2, pp. 109-121, 2007. doi: 10.1111/j.1600-0668.2006.00459.x

[3] World Health Organization, "WHO Air Quality Guidelines for Particulate Matter, Ozone, Nitrogen Dioxide and Sulfur Dioxide," 2006 [online]. Available: https://apps.who.int/iris/bitstream/handle/10665/69477/WHO_SDE_PHE_OEH_06.02 _eng.pdf;jsessionid=FCAD3C6B321FA576F722012C320CC766?sequence $=1$ [Accessed: September 2020]

[4] D.W.C. Martinez, and A.Y. Chua, "New design and automation concept of an energyefficient, tertiary building for mixed-mode ventilation system," International Journal of Automation and Smart Technology, Vol. 7, No. 4, pp. 163-178, 2017. doi: 10.5875/ausmt.v7i4.1290

[5] A. Tribess, C. Mendes Jr., C.H. Oliveira, G.S. Graudenz, J. Kalil, and M.R. Latorre, "Association of air-conditioning with respiratory symptoms in office workers in tropical climate,” Indoor Air, Vol. 15, No. 1, pp. 62-66, 2005. doi: 10.1111/j.16000668.2004.00324.x 
[6] B.W. Dionova, E. Yusuf, M.N. Mohammed, and S. Al-Zubaidi, "Environment indoor air quality assessment using fuzzy inference system,” ICT Express, Vol. 6, No. 3, pp. 185194, 2020. doi: 10.1016/j.icte.2020.05.007

[7] American Society of Heating, Refrigerating and Air-Conditioning Engineers, Inc. (ASHRAE), 2017 ASHRAE® Handbook - Fundamentals, SI Edition, Atlanta, United States, 2017.

[8] A.A. Allana, C.I.L. Razo, C.J.C.C. Docta, E.G. Ong, and F.L. Javier, Assessing the Effectiveness of Ventilation in maintaining Air Quality inside the Public Urban Airconditioned Bus, Unpublished undergraduate thesis, University of Santo Tomas, Manila, Philippines, 2016.

[9] L.Y. Chan, and Y.M. Liu, "Carbon monoxide levels in popular passenger commuting modes traversing major commuting routes in Hong Kong," Atmospheric Environment, Vol. 35, No. 15, pp. 2637-2646, 2001. doi: 10.1016/S1352-2310(00)00450-7

[10] E. Melaniuk-Wolny, K. Widziewicz, and M. Żak, "The exposure of pedestrians, drivers and road transport passengers to nitrogen dioxide," Atmospheric Pollution Research, Vol. 8, No. 4, pp. 781-790, 2017. doi: 10.1016/j.apr.2016.10.011

[11] C.-H. Yu, and W.-K. Jo, "Public bus and taxicab drivers' exposure to aromatic worktime volatile organic compounds," Environmental Research Section A, Vol. 86, pp. 6672, 2001. Available: doi: 10.1006/enrs.2001.4257

[12] C.-C. Chan, G.-R. Her, and S.-H. Lin, "Student's exposure to volatile organic compounds while commuting by motorcycle and bus in Taipei city," Air \& Waste, Vol. 43, No. 9, pp. 1231-1238, 1993. doi: 10.1080/1073161X.1993.10467200

[13] A. Milcova, I. Solansky, P. Rossner, R.J. Sram, V. Svecova, and Z. Lnenickova, "Seasonal variability of oxidative stress markers in city bus drivers. Part I: Oxidative damage to DNA," Mutation Research - Fundamental and Molecular Mechanisms of Mutagenesis, Vol. 642, No. 1-2, pp. 14-20, 2008. doi: 10.1016/j.mrfmmm.2008.03.003

[14] Tecam Group, “What are acceptable VOC levels in the air?,” 2019 [Online]. Available: https://www.tecamgroup.com/acceptable-voc-levels/ [Accessed: September 2020]

[15] European Commission, “Air Quality Standards,” [Online]. Available: https://ec.europa.eu/environment/air/quality/standards.htm [Accessed: September 2020]

[16] California Air Resources Board, "Inhalable Particulate Matter and Health (PM2.5 and PM10)," [Online]. Available: https://ww2.arb.ca.gov/resources/inhalable-particulatematter-and-health [Accessed: September 2020]

[17] J.L.P. Piquero, V.K. Delica, A.L. Orquia, E.M. Reynaldo, J. Ilao, M.A. Roque, E. Sybingco, A. Chua, J. Katupitya, and H. Jayakody, "A new sliding mode controller implementation on an autonomous quadcopter system," International Journal of Automation Smart Technology, Vol. 9, No. 2, pp. 53-63, 2019.

[18] A. Chua, and J. Katupitiya, "Kalman filters for the identification of uncertainties in robotic contact," Proceedings of the $37^{\text {th }}$ IEEE Conference on Decision Control, Vol. 2, pp. 2013-2018, 1998. Doi: 10.1109/CDC.1998.758624 